\title{
Synthesis, Structural Characterization and Biological Studies of Metal Complexes with (E)-4-oxo-4-(thiazol-2-ylamino)but-2- enoic Acid
}

\author{
SUMMIA REHMAN ${ }^{1}$, MUHAMMAD IMRAN ${ }^{1 *}$, AYESHA KANWAL ${ }^{1}$, \\ SHOOMAILA LATIF ${ }^{2}$, FIZA AKBAR ${ }^{1}$, LIVIU MITU ${ }^{3 *}$ \\ ${ }^{1}$ Institute of Chemistry, University of the Punjab, Lahore-54590, Pakistan \\ ${ }^{2}$ Department of Chemistry, The University of Lahore, Lahore \\ ${ }^{3}$ University of Pitesti, Department of Nature Sciences, 1 Targu din Vale Str., 110040, Pitesti, Romania
}

\begin{abstract}
Carboxylate functionalized ligand (LH) was synthesized as a result of reaction between maleic anhydride and 2-aminothiazole. This ligand was further reacted with $\mathrm{Co}(\mathrm{II}), \mathrm{Ni}(\mathrm{II}), \mathrm{Cu}(\mathrm{II})$, $\mathrm{Zn}(\mathrm{II})$ and Bi(III) ions to yield respective metal complexes. The structural aspects were studied using FTIR, UV-Visible and ${ }^{1} H$-NMR spectroscopy. Non-electrolytic behavior was revealed by the conductivity measurements. Except Bi(III) being octahedral, all other complexes prepared are tetrahedral in geometry. Ligand (LH) and its metal complexes were also investigated for their in vitro antibacterial and antifungal activities. All the complexes exhibited significant antibacterial activity but non-significant antifungal activity.
\end{abstract}

Keywords:Aminothiazole, Metal complexes, Spectroscopic characterization, Antibacterial, Antifungal

\section{Introduction}

An important heterocyclic compound thiazole, is biologically active in many drug structures,for exampleritonavir (anti-HIV drug) [1], nitazoxanide (antiparasitic agent) [2], nizatidine (antiulcer agent) [3], etc. It is well reported in literature that thiazole is an important core moiety in the development of drugs and theurapeutic agents [4]. A number of aminothiazole such as benzothiazoles [5], phenolic thiazoles [6] and tetrahydrobenzothiazoles [7] are reported as neuroprotective. Moreover, some of thiazole derivatives (pyrimidyl thiazole and ethynyl thiazole) behave as good glutamate receptors against anxiety complaints $[8,9]$.

2-Aminothiazole derivatives have been reported since years for diverse purposes such as dischargeable monoazo dyes [10,11], drugs against peptic ulcer [12], dermatomycoses [13], bronchitis, pneumonia, sinisytis, frangitis [14] and bipolar disorder [15], etc. Considering structure and biological significance of 2-aminothiazole, its reaction with maleic anhydride was carried out to produce ligand(LH), which was further reacted with $\mathrm{Co}(\mathrm{II}), \mathrm{Ni}(\mathrm{II}), \mathrm{Cu}(\mathrm{II}), \mathrm{Zn}(\mathrm{II})$ and $\mathrm{Bi}(\mathrm{III})$ ions to yield respective metal complexes, whose structural, antibacterial and antifungalactivities are part of this manuscript.

\section{Materials and methods}

2-Aminothiazole (Sigma Aldrich), acetic acid, maleic anhydride ( $\mathrm{M}$ and B Chem.), methanol,

$\mathrm{CoCl}_{2} .6 \mathrm{H}_{2} \mathrm{O}$ (Uni Chem.), $\mathrm{NiCl}_{2} .6 \mathrm{H}_{2} \mathrm{O}$ (United Lab.), $\mathrm{CuCl}_{2} .2 \mathrm{H}_{2} \mathrm{O}$ (Fluka Chemika),

$\mathrm{ZnCl}_{2}$ (Riedel-de-Haen), $\mathrm{BiCl}_{3}$ (Beijing Chem.), were purchased and used as such. The use of preoven dried glassware(Make; Pyrex)was ensured for synthetic and screening process.

\section{Synthesis}

Ligand (LH) was synthesized by following a reported method $[16,17]$ with minor modifications. The reactants i.e. maleic anhydride $\left(4.903 \mathrm{~g} / 5 \times 10^{-2} \mathrm{~mol}\right)$ and 2 -aminothiazole $\left(5.007 \mathrm{~g} / 5 \times 10^{-2} \mathrm{~mol}\right)$

*email: imran_inorganic@yahoo.com; ktm7ro@yahoo.com 
were separately dissolved in glacial acetic acid $(10 \mathrm{~mL})$. Then both the solutions were mixed and made to stir overnight at $25^{\circ} \mathrm{C}$. Precipitation of pale yellow color occurred and was filtered, washed with glacial acetic acid, n-pentane and subsequently dried for further use.

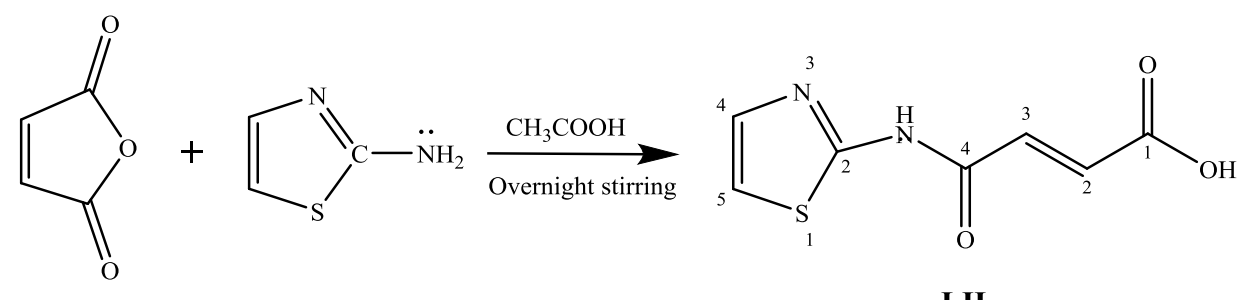

Scheme 1. Synthetic route of LH

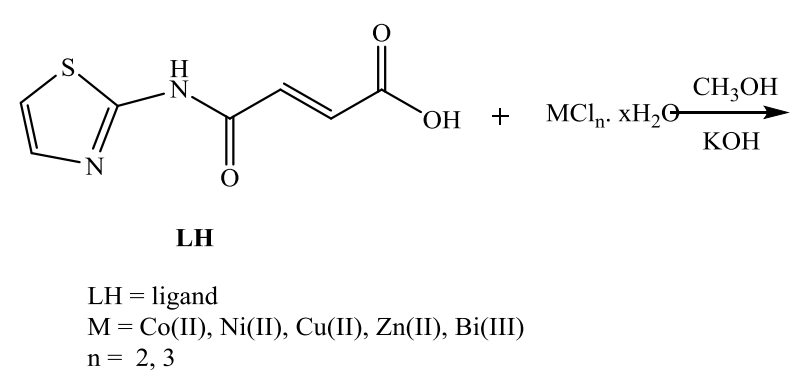

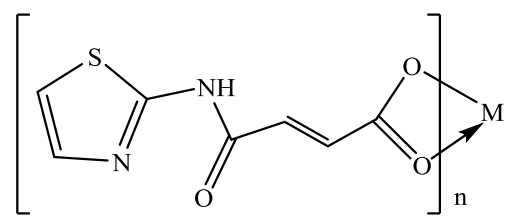

Scheme 2. Synthetic route of -metal complexes

Determination of melting points was done by Gallon Kamp apparatus while UV-visible and FT-IR spectra were obtained by Perkin Elmer multimode T90+ and Cary 630, respectively. Similarly, metal contents were foundby Atomic absorption spectrophotometer GBC model 400 XplorAA Dual. Conductivity meter Cond 720 was used to measure electrical conductivity. Five bacterial stains Bacillus subtilis, Staphylococcus aureus(gram positive),Escherichiacoli, Pseudomonas aeruginosa, Salmonella typhi(gram negative), were used to test antibacterial activity of the ligand (LH) and complexes by disc diffusion method. Similarly, fungal stains i.eCandida albicans, Trichphyton rubrum, Aspergillus niger, Microsporum canis, Fusarium liniwere used to find anti-fungal potential of the ligand (LH) and its complexes by agar tube dilution protocol.

\section{Results and discussions}

The ligand (LH) and its metal complexes were synthesized as outlined in Schemes 1 and 2. Both, the ligand (LH) andmetal complexes were obtained in appreciable to good yield and are stable towards air. These are good soluble in common organic solvents but best soluble in DMF and DMSO (Table 1). Conductometric data revealed that all the metal complexes are practically non-electrolyte (low molar electrical conductivity with values in the range $\left.1.6-7.5 \Omega^{-1} . \mathrm{cm}^{2} . \mathrm{mol}^{-1}\right)[18,19]$.

Generally, the resulting metal complexes exhibited tetrahedral geometry except $\mathrm{Bi}$ (III)-complex which exhibited octahedral geometry. The geometry of these complexes (electronicspectra) was proposed on the basis metal/ligand ratio elucidated from the data obtained through ICP-MS/AAS and elemental analyses (Table 2). 
Table 1. Physical characteristics and molar conductivity values of - $\mathrm{lh}$ and its metal complexes

\begin{tabular}{|c|c|c|c|c|}
\hline Compound & $\begin{array}{l}\text { MeltingP } \\
\operatorname{oint}\left({ }^{\circ} \mathrm{C}\right)\end{array}$ & Color & $\begin{array}{c}\text { Conductance } \\
\left(\Omega^{-1} \cdot \mathrm{cm}^{2} \cdot \mathrm{mol}^{-1}\right)\end{array}$ & Solubility \\
\hline LH & $78-82$ & $\begin{array}{l}\text { Pale } \\
\text { Yellow }\end{array}$ & - & $\begin{array}{l}\text { water, methanol, ethanol, DMSO, } \\
\text { DMF, acetone, acetonitrile }\end{array}$ \\
\hline$\left[\mathrm{Co}(\mathrm{L})_{2}\right]$ & $54-60$ & Blue & 7.49 & $\begin{array}{l}\text { water, ethanol, DMSO, DMF, acetone, } \\
\text { acetonitrile }\end{array}$ \\
\hline$\left[\mathrm{Ni}(\mathrm{L})_{2}\right]$ & $\sim 58$ & $\begin{array}{l}\text { Light } \\
\text { Green }\end{array}$ & 3.08 & DMSO, DMF \\
\hline$\left[\mathrm{Cu}(\mathrm{L})_{2}\right]$ & $65-70$ & Green & 1.66 & ethanol, DMSO, DMF \\
\hline$\left[\mathrm{Zn}(\mathrm{L})_{2}\right]$ & 140 & White & 4.76 & water, methanol, DMSO, DMF \\
\hline$\left[\mathrm{Bi}(\mathrm{L})_{3}\right]$ & $72-74$ & Yellow & 3.38 & methanol, ethanol, DMSO, DMF \\
\hline \multicolumn{5}{|c|}{$\begin{array}{l}\text { Dimethyl formamide (DMF) } \\
\text { Dimethyl sulfoxide (DMSO) }\end{array}$} \\
\hline
\end{tabular}

Table 2. Chemical composition of ligand (LH) and its complexes

\begin{tabular}{|c|c|c|c|c|}
\hline Compound & $\begin{array}{c}\text { C (\%) } \\
\text { Calc. } \\
\text { (Found) }\end{array}$ & $\begin{array}{c}\text { H (\%) } \\
\text { Calc. } \\
\text { (Found) }\end{array}$ & $\begin{array}{c}\text { N (\%) } \\
\text { Calc. } \\
\text { (Found) }\end{array}$ & $\begin{array}{c}\text { Metal(\%) } \\
\text { Calc. } \\
\text { (Found) }\end{array}$ \\
\hline $\mathrm{LH}$ & $42.42(41.12)$ & $3.05(2.78)$ & $14.13(12.79)$ & - \\
\hline$\left[\mathrm{Co}(\mathrm{L})_{2}\right]$ & $37.09(36.17)$ & $2.22(1.89)$ & $12.36(11.31)$ & $13.00(12.76)$ \\
\hline$\left[\mathrm{Ni}(\mathrm{L})_{2}\right]$ & $37.11(36.65)$ & $2.22(2.01)$ & $12.37(11.76)$ & $12.95(12.62)$ \\
\hline$\left[\mathrm{Cu}(\mathrm{L})_{2}\right]$ & $36.72(35.22)$ & $2.20(1.76)$ & $12.24(11.56)$ & $13.88(13.23)$ \\
\hline$\left[\mathrm{Zn}(\mathrm{L})_{2}\right]$ & $36.57(34.88)$ & $2.19(1.97)$ & $12.19(11.09)$ & $14.22(13.57)$ \\
\hline$\left[\mathrm{Bi}(\mathrm{L})_{3}\right]$ & $31.51(31.11)$ & $1.87(1.67)$ & $10.50(9.21)$ & $26.10(25.30)$ \\
\hline
\end{tabular}

\section{UV-Visible electronic spectra}

UV-Visible spectrum of Ligand (LH) showed a peak at $280 \mathrm{~nm}$ which can be assigned to $\pi-\pi^{*}$ transition. The electronic spectrum of the Co(II)-complex suggests tetrahedralconfiguration for the complex; the spectrum shows a broadband around $17950 \mathrm{~cm}^{-1}(557 \mathrm{~nm})$ assignable to ${ }^{4} \mathrm{~A}_{2}(\mathrm{~F}) \rightarrow{ }^{4} \mathrm{~T}_{1}(\mathrm{P})$ transition of tetrahedral cobalt(II); the magnetic moment value (4.18 B.M.) and the blue color of the cobalt(II) complex, also suggest tetrahedral stereochemistry [20]. The spectrum of the Ni(II) complex, exhibits one band at $15128 \mathrm{~cm}^{-1}(661 \mathrm{~nm})$ assigned to ${ }^{3} \mathrm{~T}_{1}(\mathrm{~F}) \rightarrow{ }^{3} \mathrm{~T}_{1}(\mathrm{P})$ transition in a tetrahedralgeometry around $\mathrm{Ni}$ (II) ion [21]; the value of magnetic moment (3.72 B.M.) falls in the range reported for tetrahedral geometry around a $\mathrm{Ni}(\mathrm{II})$ ion [21]. $\mathrm{Cu}$ (II) ions in the tetrahedral ligand

fields do not show any electronic absorption band in the region $20000-12500 \mathrm{~cm}^{-1}$; however, the $\left[\mathrm{Cu}(\mathrm{L})_{2}\right]$ complex shows broad band at $\approx 25000 \mathrm{~cm}^{-1}$; this can be assigned to charge transfer. Since no spectral bands are present in the range $20000-12500 \mathrm{~cm}^{-1}$, the complex $\mathrm{Cu}$ (II) is expected to have a distorted tetrahedral stereochemistry; the magnetic moment value of (1.98 B.M.) also supports the tetrahedral geometry of $\mathrm{Cu}(\mathrm{II})$ complex [22]. In the spectrum of the $\left[\mathrm{Zn}(\mathrm{L})_{2}\right]$ complex is revealed an intense absorption at $24096 \mathrm{~cm}^{-1}(415 \mathrm{~nm})$; assigned to the charge transfer transition $\mathrm{L} \rightarrow \mathrm{M}$ and the complex is diamagnetic [23]. From the electronic spectrum of the complex the geometry of the metallic ion cannot be precise but taking in consideration the ligand functions in a bidentate form as well as the tendency of the $\mathrm{Zn}$ (II) ion for the tetrahedral stereochemistry in the tetra-coordination complexes, we suggest a tetrahedral configuration [23]. The shifting of bands inBi(III) complex towards bathochromicregion when compared with LH indicate the involvement of ligand (LH) in the chelation with $\mathrm{Bi}(\mathrm{III})$ ion [24]. 


\section{FT-IR spectral analysis}

Characteristic bond frequencies between the range $4000-700 \mathrm{~cm}^{-1}$, were noted for ligand (LH) and its complexes. FT-IR spectrum of ligand (Figure 1) displaying peaks at $3022 \mathrm{~cm}^{-1}$ and1304 $\mathrm{cm}^{-}$ ${ }^{1}$ are assigned to $\mathrm{N}-\mathrm{H}$ group and $\mathrm{C}-\mathrm{N}$ group respectively. Similarly, the peaks at $1512 \mathrm{~cm}^{-1}$ and 1351 $\mathrm{cm}^{-}$are the depiction of carboxylate moiety in $\mathrm{LH}$, assigned to asymmetric and symmetric vibrations, respectively. The presence of these peaks in (LH) supports its recommended structure. The contribution of $\mathrm{COO}^{-}$moiety was clearly noted in favor of proposed structures, on comparing the shifts in spectra of LH and its complexes [25]. The difference $(\Delta v)$ of $v(\mathrm{COO})$ asym and $v(\mathrm{COO})$ sym was observed to be $<200 \mathrm{~cm}^{-1}$, that supports monoanionic bidentate nature of ligand (LH) [26, 27]. No other significant shift was observed in other functional moieties of ligand like $\mathrm{C}=\mathrm{O}$ and $\mathrm{NH}$,etc.

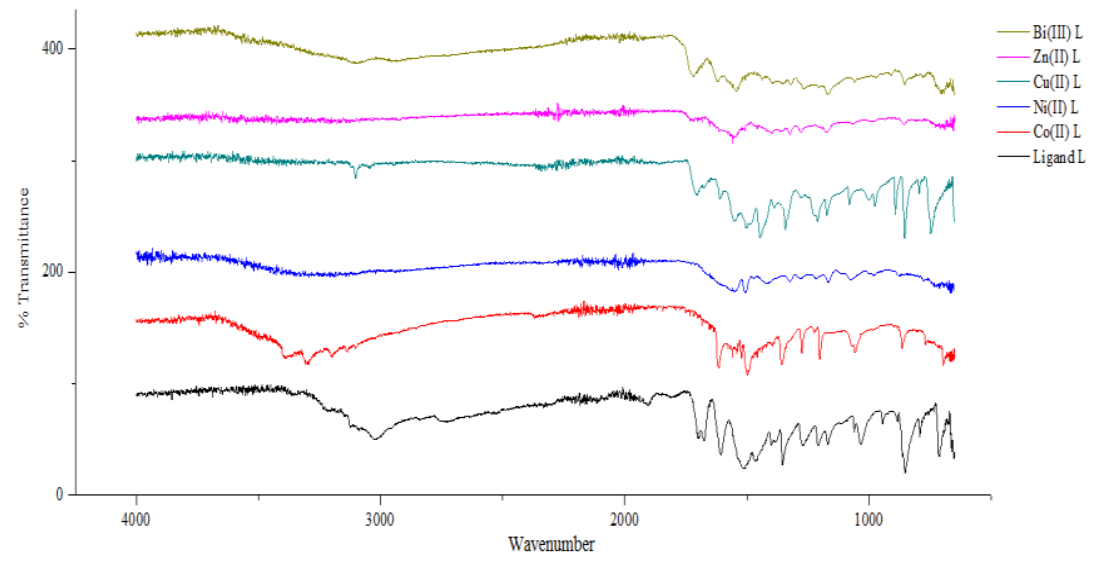

Figure 1. ComparativeFT-IR graph of LH complexes

\section{NMR spectra}

${ }^{1} \mathrm{H}-\mathrm{NMR}$ spectra of $(\mathrm{LH})$ and $\left[\mathrm{Zn}(\mathrm{L})_{2}\right]$ complex were recorded in DMSO-d ${ }_{6}$ (Figures 2 and 3). The ${ }^{1} \mathrm{H}-\mathrm{NMR}$ spectrum of ligand (LH) depicted a broad singlet in the range 12.533-12.601 ppm for $\mathrm{NH} / \mathrm{OH}$ group, two doublets in the range 7.494-7.503 ppm and 7.247-7.256 ppm that could be attributed to $\mathrm{C}-\mathrm{H}$ protons $\left(\mathrm{H}_{1}\right.$ and $\left.\mathrm{H}_{2}\right)$ of thiazole ring. Another doublet peak appearing in the range 6.459-6.466 ppm can be attributed to the presence of protons $\mathrm{H}_{5}$ and $\mathrm{H}_{6}$ in the vicinity of carboxylic group (Table 3). ${ }^{1} \mathrm{H}-\mathrm{NMR}$ spectrum of $\mathrm{Zn}$ (II) complex provided fine information about the chemical shifts of protons which is in accordance with proposed monoanionic bidentate mode of ligand. The notable change is the disappearance of $-\mathrm{OH}$ signal at $12.601 \mathrm{ppm}$ indicating its deprotonation and involvement with $\mathrm{Zn}(\mathrm{II})$ ion. Similar data were obtained from ${ }^{13} \mathrm{C}-\mathrm{NMR}$ spectra. The coordination of metal ion via carboxylate moiety was confirmed by a slight chemical shift shown by its carbon [$\left.\mathrm{C}=\mathrm{O},(\mathrm{LH}) 176.1 \mathrm{ppm} ;\left[\mathrm{Zn}(\mathrm{L})_{2}\right] 174.6 \mathrm{ppm}\right]$.

Table 3. ${ }^{1} \mathrm{H}-\mathrm{NMR}$ data of ligand (lh) and its zn(ii) complex

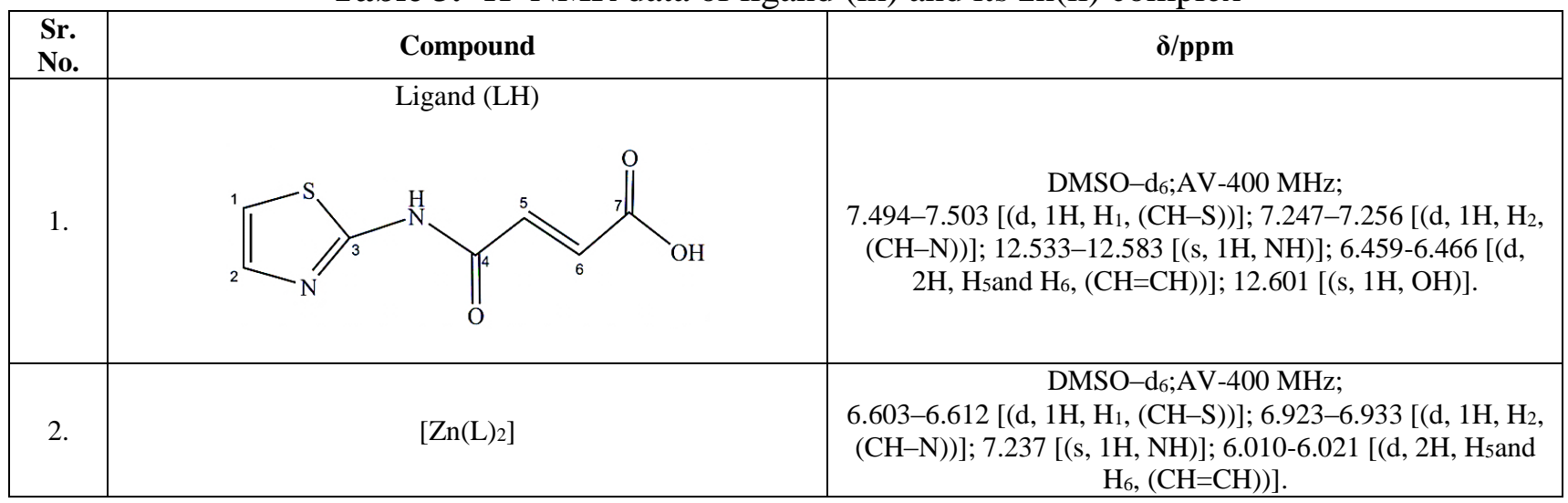




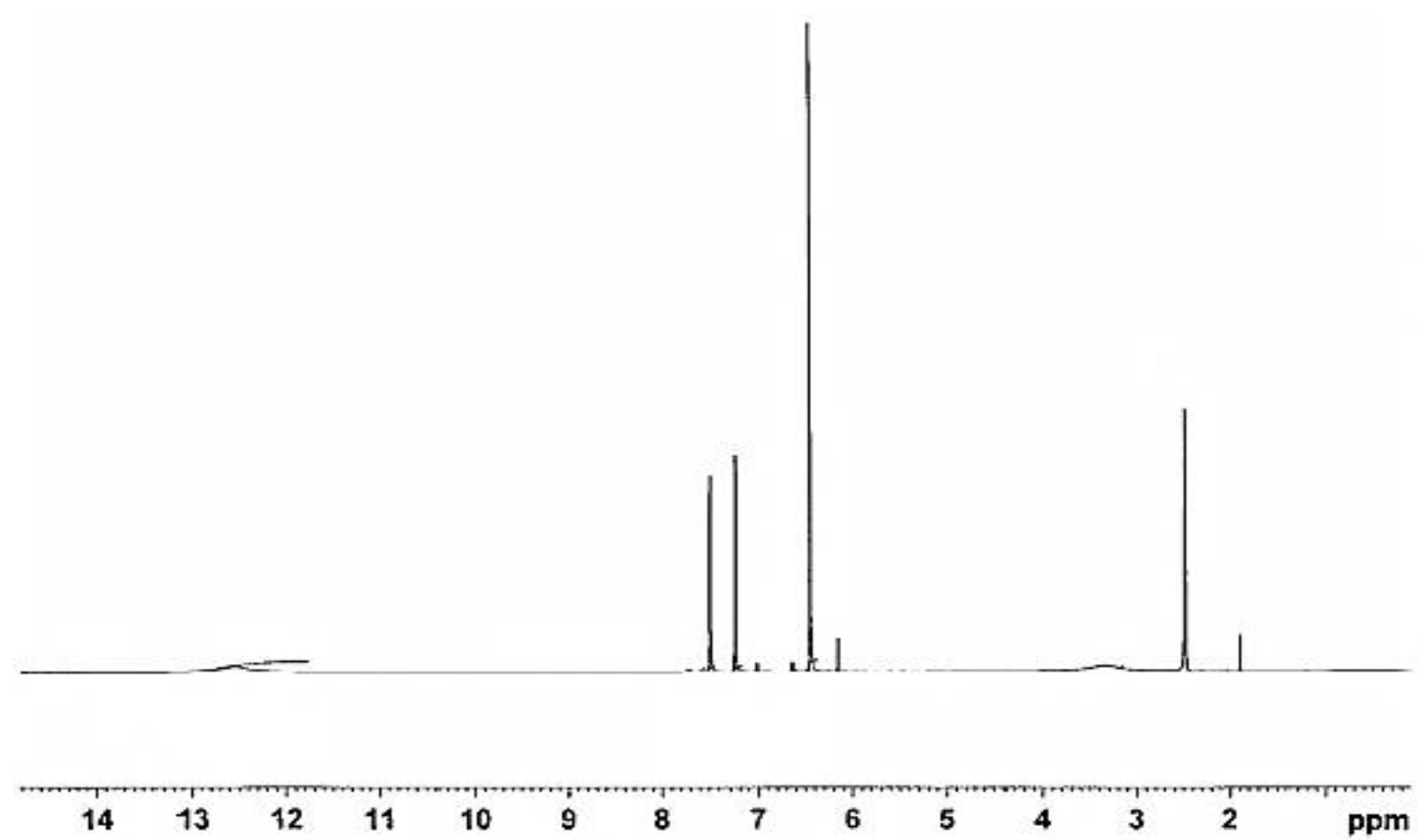

Figure 2. ${ }^{1} \mathrm{HNMR}$ spectrum of ligand (LH)

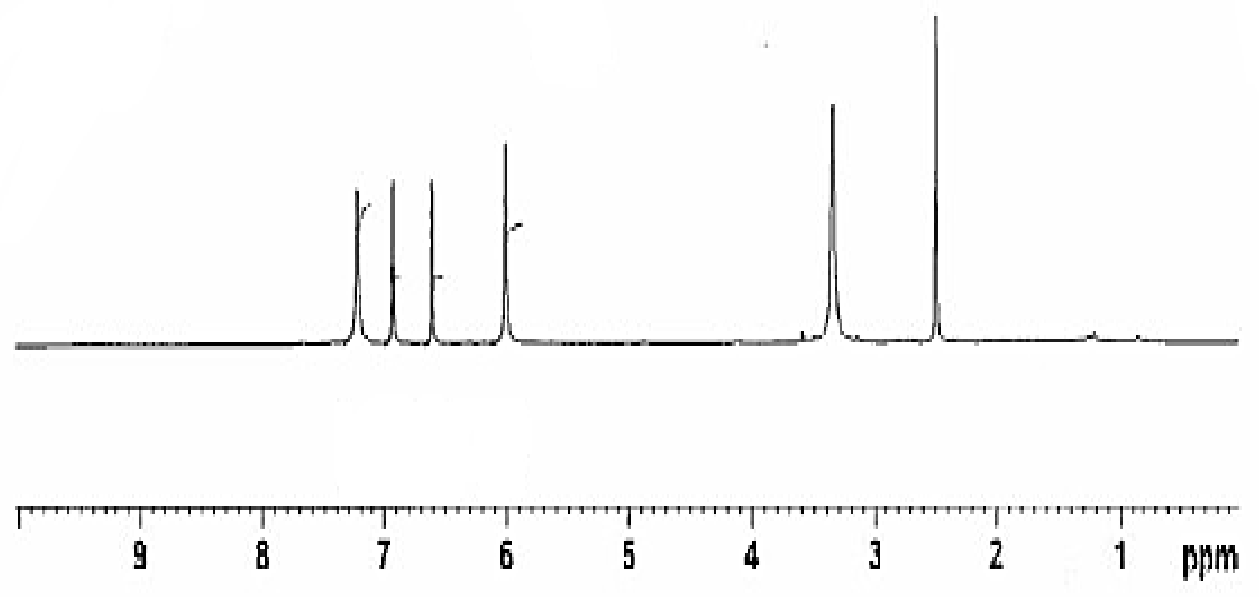

Figure 3. ${ }^{1} \mathrm{HNMR}$ spectrum of $\mathrm{Zn}\left(\mathrm{L}_{2}\right)$ complex

\section{Biological studies}

Antibacterial and antifungal studies

Tests against five bacterial strains were conducted for the antibacterial potency of prepared ligand LH and complexes made, using disc diffusion method [27-30]. Among these bacterial stainstwo were gram positive bacteria such as Bacillus subtilis, Staphylococcus aureus and three were gram negative bacteria such as Escherichia coli, Pseudomonas aeruginosa and Salmonella typhi. Generally metal complexes exhibited non-significant action against most of the bacterial strains except $\left[\mathrm{Co}(\mathrm{L})_{2}\right]$ and [Zn(L)2] complexes which exhibited significant activity against Staphylococcus aureus (Table 4). 
Table 4. Data presenting antibacterial potentialof $\mathrm{lh}$ and its metal complexes

\begin{tabular}{|c|c|c|c|c|c|c|c|}
\hline \multirow{2}{*}{$\begin{array}{c}\text { Name of } \\
\text { Bacteria }\end{array}$} & $\begin{array}{c}\text { Percent (\%) } \\
\text { inhibition of } \\
\text { drug }\end{array}$ & $\begin{array}{c}\text { Ligand } \\
(\mathrm{LH})\end{array}$ & {$\left[\mathrm{Co}(\mathrm{L})_{2}\right]$} & {$\left[\mathrm{Ni}(\mathrm{L})_{2}\right]$} & {$\left[\mathrm{Cu}(\mathrm{L})_{2}\right]$} & {$\left[\mathrm{Zn}(\mathrm{L})_{2}\right]$} & {$\left[\mathrm{Bi}(\mathrm{L})_{3}\right]$} \\
\hline $\begin{array}{c}\text { Escherichia } \\
\text { Coli }\end{array}$ & 86.2 & 17.5 & - & 11 & - & 10 & - \\
\hline $\begin{array}{c}\text { Bacillus } \\
\text { Subtilis }\end{array}$ & 95.6 & 15.5 & - & - & 16.7 & - & 12.6 \\
\hline $\begin{array}{c}\text { Staphylococcus } \\
\text { Aureus }\end{array}$ & 93.7 & 17.0 & 47.5 & - & - & 70.5 & - \\
\hline $\begin{array}{c}\text { Pseudomonas } \\
\text { Aeruginosa }\end{array}$ & 95.5 & 11.00 & - & - & - & - & 11 \\
\hline $\begin{array}{c}\text { Salmonella } \\
\text { Typhi }\end{array}$ & 96.7 & 13.5 & - & 7.5 & 14.5 & - & - \\
\hline \multicolumn{7}{|c|}{ Ligand (LH) is (E)-4-oxo-4-(thiazol-2-ylamino)but-2-enoicacid; } \\
sign - means No inhibition
\end{tabular}

Antifungal potential of ligand (LH)and its metal complexes was investigated against five fungal strains i.e.Fusarium lini, Trichphyton rubrum, Aspergillus nigerCandida albicansand Microsporum canis via agar tube 'dilution' protocol [30]. Preliminary screening of in vitro antifungal bioassay was carriedout using $400 \mu \mathrm{g} / \mathrm{mL}$ concentration of each compound (in DMSO) by Agar Tube Dilution Protocol. Minimum inhibitory concentration (MIC) of two drugs was also calculated against each of the five fungi through this protocol. Dilution plates (containing solution of each compound and melted agar) were incubated at $27^{\circ} \mathrm{C}$ for 7 days in order to ensure growth of fungus. Inhibitory action was determined (as percentage) for each sample against each of the five fungi.The MIC values as determined for LH and metal complexes were in the range 5.6 to 13.5 (Table 5). When compared with MIC values of reference drugs, almost all the metal complexes displayed insignificant activity against several fungal strains.

Table 5. Data presenting antifungal potential of lhand metal complexes

\begin{tabular}{|c|c|c|c|c|c|c|c|c|}
\hline \multirow[b]{2}{*}{ Fungus name } & \multirow[b]{2}{*}{$\begin{array}{c}\text { Drug } \\
\text { (Standard) }\end{array}$} & \multirow[b]{2}{*}{$\underset{(\mu \mathrm{g} / \mathrm{mL})}{\mathrm{MIC}}$} & \multicolumn{6}{|c|}{ Percent (\%) inhibition of compound } \\
\hline & & & $\begin{array}{c}\text { Ligand } \\
(\mathrm{LH})\end{array}$ & {$\left[\mathrm{Co}(\mathrm{L})_{2}\right]$} & {$\left[\mathrm{Ni}(\mathrm{L})_{2}\right]$} & {$\left[\mathrm{Cu}(\mathrm{L})_{2}\right]$} & {$\left[\mathrm{Zn}(\mathrm{L})_{2}\right]$} & {$\left[\mathrm{Bi}(\mathrm{L})_{3}\right]$} \\
\hline $\begin{array}{l}\text { Candida } \\
\text { albicans }\end{array}$ & Miconazole & 97.8 & 10.0 & - & - & - & - & - \\
\hline $\begin{array}{c}\text { Trichphyton } \\
\text { rubrum }\end{array}$ & ” & 113.5 & - & - & 8.5 & - & - & 13.5 \\
\hline $\begin{array}{l}\text { Microsporum } \\
\text { canis }\end{array}$ & $"$ & 98.1 & 5.8 & - & 11 & - & - & 5.6 \\
\hline $\begin{array}{l}\text { Fusarium } \\
\text { Lini }\end{array}$ & & 73.50 & - & - & - & - & 9.5 & - \\
\hline $\begin{array}{c}\text { Aspergillus } \\
\text { niger }\end{array}$ & $\begin{array}{c}\text { Amphotericin } \\
\text { B } \\
\end{array}$ & 20.70 & - & - & - & - & 12.4 & - \\
\hline & Liga & $\begin{array}{l}\text { The } m \\
\text { H) mean }\end{array}$ & $\begin{array}{l}\text { um inhit } \\
\text {-4-oxo- } \\
\text { ign - me }\end{array}$ & $\begin{array}{l}\text { ry concen } \\
\text { hiazol-2-y } \\
\text { No inhibi }\end{array}$ & $\begin{array}{l}\text { ion (MIC } \\
\text { nino)but- }\end{array}$ & noic acid; & & \\
\hline
\end{tabular}

\section{Conclusions}

Ligand ( $\mathrm{LH})$ and its five metal complexes containing carboxylate moiety were prepared and characterized. Ligand (LH) behaved in a monoanionic bidentate manner that resultsinto one octahedral and four tetrahedral complexes. Co(II) and $\mathrm{Zn}$ (II) complexes exhibited significant antibacterial activity. The incorporation of thiazole moiety in the system together with $\mathrm{Co}$ (II) and $\mathrm{Zn}$ (II) complexes can be investigated in-vivo for further model studies, a step towards development of metal based drugs. 


\section{References}

1.DE SOUZA, M.V.N., DE ALMEIDA, M.V., Química Nova, 26, 2003, p. 366

2.FOX, L.M., SARAVOLATZ, L.D., Clinical Infectious Diseases, 40, 2005, p. 1173

3.KNADLER, M.P., BERGSTROM, R.F., CALLAGHAN, J.T., RUBIN, A.L.A.N., Drug Metabolism and Disposition, 14, 1986, p. 175

4.AYATI, A., EMAMI, S., ASADIPOUR, A., SHAFIEE, A., FOROUMADI, A., Eur.J.Med.Chem., 97, 2015, p. 699

5.AVILA, B., ROTH, A., STREETS, H., DWYER, D.S., KURTH, M.J., Bioorganic \&Med. Chem.Lett., 22, 2012, p. 5976

6.MISHRA, C.B., KUMARI, S., TIWARI, M., Eur.J.Med.Chem., 92, 2015, p. 1

7.HARNETT, J.J., ROUBERT, V., DOLO, C., CHARNET, C., SPINNEWYN, B., CORNET, S., CHABRIER, P.E., Bioorganic \& Med.Chem.Lett., 14, 2004, p. 157

8.SATOH, A., NAGATOMI, Y., HIRATA, Y., ITO, S., SUZUKI, G., KIMURA, T., MAEHARA, S., Bioorganic \& Med.Chem.Lett., 19, 2009, p. 5464

9.HONG, S.P., LIU, K.G., MA, G., SABIO, M., UBERTI, M.A., BACOLOD, M.D., PETERSON, Z.Z., J. Med.Chem., 54, 2011, p. 5070

10.MARADIYA, H.R., PATEL, V.S., Chem.Hetero.Comp., 39, 2003, p.357

11. BRODKIN, V. F., SEMENOVA, T. S., Khim. Khim Technol., 12, 1969, p. 1716

12.LAINE, L., KIVITZ, A.J., BELlO, A.E., GRAHN, A.Y., SCHIFF, M.H., TAHA, A.S., Am.J. Gastro., 107, 2012, p. 379

13.BORELli, C., SCHALLER, M., NIEWERTH, M., NOCKER, K., BAASNER, B., BERG, D., TIEMANN, R., Chemotherapy, 54, 2008, p. 245

14.GUAY, P.D.R., Clin.Ther., 24, 2002, p. 473

15. GOLDBERG, J.F., BURDICK, K.E., ENDICK, C.J., Am.J.Psychiatry, 161, 2000, p. 564

16.IMRAN, M., NAZIR, S., LATIF, S., MAHMOOD, Z., J.Chem.Soc.Pak., 32, 2010, p. 492

17. SHAHID, K., ALI, S., SHAHZADI, S., AKHTAR, Z., Turk.J.Chem., 27, 2003, p. 209

18.IQBAL, J., IMRAN, M., IQBAL, S., LATIF, S., J.Chem.Soc.Pak., 29, 2007, p. 151

19.AL-AZZAWI, A., ABDULRAHMAN, S., Baghdad Sci.J., 7, 2010, p. 1

20.KONSTANTINOVIC, S.S., RADOVANOVIC, B.C., CAKIC, Z., VASIC, V., J.Serb.Chem.Soc.,

68, 2003,p. 641

21.HOSNY, N.M., IBRAHIM, R., EL-ASMY, A.A.,J.Serb.Chem.Soc., 81, 2016, p. 57

22.ABDEL AZIZ, A.A., SHAWKY, A., KHALIL, M.H., Appl.Organomet.Chem., 32, 2018,p. 4404

23.MITU, L., RAMAN, N., KRIZA, A., STĂNICĂ, N., DIANU, M., Asian J.Chem., 21,

2009 , p. 5749

24.KANWAL, A., IMRAN, M., IQBAL, Z., REHMAN, S., DANISH, Z., BATOOL, N., MITU, L., Rev. Chim., 69(7), 2018, 1702

25.KEMP, W., Infrared Spectroscopy, chapter 2 in: Organic Spectroscopy, $3^{\text {rd }}$ edition,Palgrave, New York, 3, 1991, p. 19

26.QING-LAN, X., ZHI-QIANG, Y., ZU-XIN, Z., DIAN-KUN, Z.,Appl.Organomet.Chem.,6, 1992, p. 193

27.SHAHID, K., ALI, S., SHAHZADI, S., BADSHAH, A., KHAN, K.M., MAHARVI, G.M., Synt.React.Inorg.Metal-Org.Chem., 33, 2003, p. 1221

28. SHAHZADI, S., SHAHID, K., ALI, S., BAKHTIAR, M., Turk.J.Chem., 32, 2008, p. 333

29.XIE, Q., YANG, Z., JIANG, L., Main Group Metal Chem., 19, 1996, p. 509

30.WIEGAND, I., HILPERT, K., HANCOCK, R. E. W., Nature Protocols, 3, 2008, p. 163.

Manuscript received: 12.11 .2019 